\title{
Changes in transforming growth factor $\beta$ and its receptors' mRNA expression in monocytes from patients with acute coronary syndromes
}

Andrzej Kulach', Jozefa Dabek ${ }^{1}$ Tadeusz Wilczok², Zbigniew Gasior ${ }^{1}$

\author{
1Department of Cardiology, Medical University of Silesia, Ziolowa 47, 40-635 Katowice, \\ Poland \\ 2Department of Molecular Biology and Medical Genetics, Medical University of Silesia, \\ ul. Narcyzów 1, Sosnowiec, Poland
}

Submitted: 11 November 2009

Accepted: 24 January 2010

Arch Med Sci 2010; 6, 4: 526-532

DOI: $10.5114 /$ aoms.2010.14463

Copyright @ 2010 Termedia \& Banach

\begin{abstract}
Introduction: Transforming growth factor $\beta$ (TGF $\beta$ ) is thought to be a vasoprotective cytokine. Numerous reports confirm its significance in blood and plaques. There is, however, a lack of information on the molecular mechanisms involving TGF $\beta$ in circulating inflammatory cells in atherogenesis. The aim of the study was to assess gene expression of TGF $\beta$ and its receptors in monocytes from patients with acute coronary syndromes (ACS) and the effect of standard treatment on the studied genes.

Material and methods: The study was carried out in 32 patients with ACS and 15 healthy subjects. Gene expression of TGF $\beta$ and receptors TGF $\beta$ RI and RII was evaluated on day 1 and 5 in the study group and once in controls. The number of mRNA copies isolated from monocytes was assessed by QRT-PCR.

Results: Monocytes of ACS patients showed slightly elevated transcriptional activity of TGF $\beta 1$ and its receptors RI and RII genes $(0.29 \pm 0.043$ vs. $0.08 \pm 0.020$, $p=0.05 ; 0.071 \pm 0.022$ vs. $0.036 \pm 0.023, p<0.05 ; 0.134 \pm 0.020$ vs. $0.048 \pm 0.016$, $p<0.05$, respectively). After 5 -day standard treatment modest reduction of TGF $\beta$ RI expression was observed. The studied genes' expression was unrelated to $E F$, myocardial necrosis markers, GRACE score, time from the onset of pain to $\mathrm{PCl}$ and angiographic findings. Among risk factors family history of CAD was associated with increased TGF $\beta$ RI expression. Moreover, the presence of 4 or more classic risk factors correlated with higher TGF $\beta$ RI expression.

Conclusion: Monocytes of ACS patients demonstrate overexpression of TGF $\beta 1$ and its receptors' genes. 5-day standard treatment downregulated the TGF $\beta$ RI gene but did not affect TGF $\beta 1$ and TGF $\beta$ RII.
\end{abstract}

Key words: monocytes, gene expression, transforming growth factor $\beta$, acute coronary syndromes.

\section{Introduction}

Acute coronary syndromes (ACS), including myocardial infarction (AMI) and unstable angina (UA), are among the leading causes of death in Western societies and have become the major concern of clinical cardiology. A number of studies over the past two decades have revealed that ACS is primarily caused by atherosclerotic plaque rupture followed by intravascular thrombosis resulting in total or partial coronary artery occlusion. Many factors responsible for the plaque vulnerability, including

\author{
Corresponding author: \\ Andrzej Kulach, MD, PhD \\ Department of Cardiology \\ Medical University of Silesia \\ Ziolowa 47 \\ 40-635 Katowice, Poland \\ tel./fax +48 322527407 \\ E-mail: \\ andrzejkulach@gmail.com
}


inflammatory factors, coagulation disturbances and endothelial dysfunction, have been described [1]. Recent molecular studies have revealed altered transcriptional activity of many pro- and antiinflammatory genes involved in plaque formation and rupture, both in atherosclerotic plaque itself and in circulating inflammatory cells in patients with ACS.

Transforming growth factor $\beta$ (TGF $\beta$ ) is a cytokine engaged in a wide range of physiological and pathological processes [2]. Apart from embryonic development and cell growth control, it participates in wound formation, carcinogenesis, inflammation, and fibrosis. TGF $\beta$ signalling is mediated by two major receptors: RI and RII - serine/threonine kinase type proteins, which eventually activate TGF $\beta$ dependent transcription factors [3].

In the pathophysiology of the cardiovascular system TGF $\beta$ seems to act mostly protectively due to its anti-inflammatory and anti-atherogenic action [4]. It inhibits activation of macrophages and T-lymphocytes, and reduces vascular smooth muscle cell proliferation $[5,6]$. In experimental models TGF $\beta$ inhibits inflammatory cell migration into the subintimal space and stimulates extracellular matrix formation [7, 8]. Although there are some data on the action of TGF $\beta$ at the protein level, not much is known about the molecular disturbances of TGF $\beta$ gene transcription in cardiovascular diseases.

Monocytes are one of two major populations of blood derived immune cells and are involved in atherosclerotic plaque formation, growth and rupture by producing numerous inflammation modulating factors. While it is difficult to obtain the plaque infiltrating immune cells, circulating blood cells are a good source of information on the molecular mechanism of the inflammatory reaction in atherosclerosis. Often used for these purposes, peripheral blood mononuclear cells (PBMC), despite some advantages, are a heterogeneous population.
Therefore, the aim of the study was to assess (1) gene expression of TGF $\beta$ and its receptors in monocytes from patients with ACS, (2) the correlation between expression of the studied genes and classical risk factors of CAD, and (3) the effect of standard treatment on expression of the studied genes.

\section{Material and methods}

\section{Patients}

The study was carried out on:

- 32 patients with acute coronary syndrome [aged $56.3 \pm 8.2$ years (mean \pm SD)] including 14 patients with ST elevation myocardial infarction (STEMI), 9 patients with non-ST elevation myocardial infarction (NSTEMI) and 9 patients with unstable angina, with no history of CAD, and

- 15 sex- and age-matched healthy subjects ( $\mathrm{C}=$ control group).

In each patient the full blood cell count, leukocyte differentiation, CK (creatine kinase), CK-MB, troponin I, hsCRP, creatinine, glycaemia and lipid parameters were measured. Patients with previously diagnosed $C A D$, including those with a history of $\mathrm{MI}$ and coronary revascularization, were excluded. Also, chronic inflammatory diseases, chronic heart failure, chronic kidney disease (eGFR < $90 \mathrm{ml} / \mathrm{min} / 1.73 \mathrm{~m}^{2}$ calculated with MDRD), as well as diabetes mellitus, were exclusion criteria. All ACS patients underwent primary coronary intervention and were treated according to European Society of Cardiology Guidelines for management in ACS. All subjects received ASA, clopidogrel and statin. ACE inhibitors (82\%) and beta-blockers (82\%) were administered unless contraindicated (Table III). Control subjects had a standard exercise treadmill test performed (Bruce protocol). Detailed characteristics of studied groups including ACS risk profile are shown in Table I. Written informed

Table I. Baseline characteristics

\begin{tabular}{|lccccc|}
\hline Parameter & \multicolumn{4}{c}{ Study Group } & Control Group \\
& ACS (all) & & Subgroups & $(n=15)$ \\
& $(n=32)$ & STEMI $(n=14)$ & NSTEMI $(n=9)$ & UA $(n=9)$ & \\
\hline Age (years \pm SD) & $56.3 \pm 8.2$ & $56.6 \pm 10.2$ & $56.6 \pm 4.4$ & $55.3 \pm 8.6$ & $51 \pm 8.6$ \\
\hline Sex, M/F & $26 / 6$ & $12 / 2$ & $7 / 2$ & $7 / 2$ & $9 / 6$ \\
\hline Family history, $n(\%)$ & $10(31 \%)$ & $3(21 \%)$ & $3(33 \%)$ & $4(44 \%)$ & $5(33 \%)$ \\
\hline Smoking, $n(\%)$ & $24(75 \%)$ & $8(57 \%)$ & $7(77 \%)$ & $7(77 \%)$ & $2(13 \%)$ \\
\hline Hypertension, $n(\%)$ & $21(66 \%)$ & $10(71 \%)$ & $5(55 \%)$ & $6(66 \%)$ & 0 \\
\hline Overweight, $n(\%)$ & $20(63 \%)$ & $7(50 \%)$ & $6(66 \%)$ & $7(77 \%)$ & $5(33 \%)$ \\
\hline BMI $[$ kg/m²] & $26.6 \pm 0.56$ & $26.2 \pm 1.05$ & $26.6 \pm 1.0$ & $27.3 \pm 0.8$ & $24.5 \pm 0.55$ \\
\hline Hypercholesterolaemia, $n(\%)$ & $17(53 \%)$ & $8(57 \%)$ & $4(44 \%)$ & $5(55 \%)$ & $3(20 \%)$ \\
\hline Hypertriglyceridaemia, $n(\%)$ & $5(16 \%)$ & $1(7 \%)$ & $1(11 \%)$ & $3(33 \%)$ & $1(7 \%)$ \\
\hline
\end{tabular}


Table II. Clinical characteristics of ACS

\begin{tabular}{|lcccc|}
\hline & \multicolumn{4}{c|}{ Study Group } \\
\cline { 2 - 5 } & ACS (all) $(n=32)$ & STEMI $(n=14)$ & NSTEMI $(n=9)$ & UA $(n=9)$ \\
\hline Time from the onset of chest pain [h] & $7.2[1-24]$ & $4.2[1-10]$ & $8.9[2-24]$ & $10.1[2-24]$ \\
\hline One-vessel / multivessel disease [n/n] & $21 / 11$ & $10 / 4$ & $6 / 3$ & $5 / 4$ \\
\hline PCI Target vessel [LAD/LCX/RCA] & $14 / 7 / 11$ & $6 / 2 / 6$ & $5 / 4 / 0$ & $3 / 1 / 5$ \\
\hline Ejection Fraction [\%] & $53 \pm 1.4$ & $50 \pm 2.0$ & $55 \pm 2.0$ & $56 \pm 3.0$ \\
\hline Myocardial necrosis markers: & & & & \\
\hline CK [UI/l] & $1471 \pm 365.6$ & $27834 \pm 674.8$ & $773 \pm 233.5$ & $124 \pm 8.8$ \\
\hline CK-MB [UI/l] & $149 \pm 31.4$ & $256 \pm 55.8$ & $111 \pm 32.4$ & $19.3 \pm 1.33$ \\
\hline Troponin I [ng/ml] & $10.5 \pm 2.18$ & $19.6 \pm 3.17$ & $7.9 \pm 3.19$ & $<0.01$ \\
\hline GRACE: In hospital death [\% range] & - & $16-25$ & $12-18$ & $6-12$ \\
\hline GRACE: 6-month death or MI [\% range] & - & $2-6$ & $1-4$ & $1-4$ \\
\hline eGFR (MDRD) & $101.5 \pm 13.4$ & $103.9 \pm 15.4$ & $98.7 \pm 10.4$ & $100.0 \pm 13.0$ \\
\hline
\end{tabular}

Table III. Pharmacological treatment of ACS patients

\begin{tabular}{|c|c|c|c|c|c|c|}
\hline & \multicolumn{3}{|c|}{ Number of pts treated [\%] } & \multicolumn{3}{|c|}{ Average dose/day [mg] } \\
\hline & STEMI & NSTEMI & UA & STEMI & NSTEMI & UA \\
\hline ASA & $14(100 \%)$ & $9(100 \%)$ & $9(100 \%)$ & 128 & 108 & 116 \\
\hline Clopidogrel & $14(100 \%)$ & 9 (100\%) & $9(100 \%)$ & 75 & 75 & 75 \\
\hline Statins: & $14(100 \%)$ & $9(100 \%)$ & $9(100 \%)$ & - & - & - \\
\hline Simvastatin & 3 & 1 & 3 & 26 & 20 & 20 \\
\hline Atorvastatin & 11 & 8 & 6 & 38 & 37.5 & 33 \\
\hline Beta-blockers & $13(93 \%)$ & $8(89 \%)$ & $7(78 \%)$ & - & - & - \\
\hline Metoprolol & 10 & 5 & 6 & 57 & 45 & 46 \\
\hline Bisoprolol & 3 & 3 & 1 & 4.6 & 2.9 & 2.5 \\
\hline ACE inhibitors & $11(79 \%)$ & $8(89 \%)$ & $9(100 \%)$ & - & - & - \\
\hline Ramipril & 8 & 8 & 8 & 3.75 & 4.1 & 3.4 \\
\hline Quinapril & 3 & 0 & 1 & 15.8 & - & 5 \\
\hline \multicolumn{7}{|l|}{ Other: } \\
\hline Spironolactone & $7(50 \%)$ & $2(22 \%)$ & 0 & 32 & 37.5 & - \\
\hline
\end{tabular}

consent was obtained from each participant of the study.

Blood samples were collected from the basilic vein into tubes containing EDTA. The samples were obtained from patients within 12 hours after the onset of chest pain and again after 5 days of standard treatment, including PCI. Time from the onset of chest pain to first blood sampling is indicated in Table II. In all cases the blood (day 1 sample) was drawn before $\mathrm{PCl}$ and before introducing full pharmacological treatment. Before the collection patients could only receive emergency ACS treatment e.g. ASA, heparin, nitrates and clopidogrel). In the control group blood was taken once. Upon blood sampling, the monocytes were immediately isolated using RosetteSep (StemCell Technologies, USA) monocyte separation kits. The procedure was performed according to the producer's manual. Purity of isolated monocytes was $>96 \%$. After isolation monocytes were stored at $-70^{\circ} \mathrm{C}$ in RNAlater (Qiagen, USA) stabilization reagent until RNA extraction.

\section{RNA extraction}

Total RNA was extracted from monocytes using a modified Chomczynski and Sacchi method. All extracts were treated with DNase I to avoid contamination by genomic DNA. The RNA extracts were qualitatively evaluated by electrophoresis 


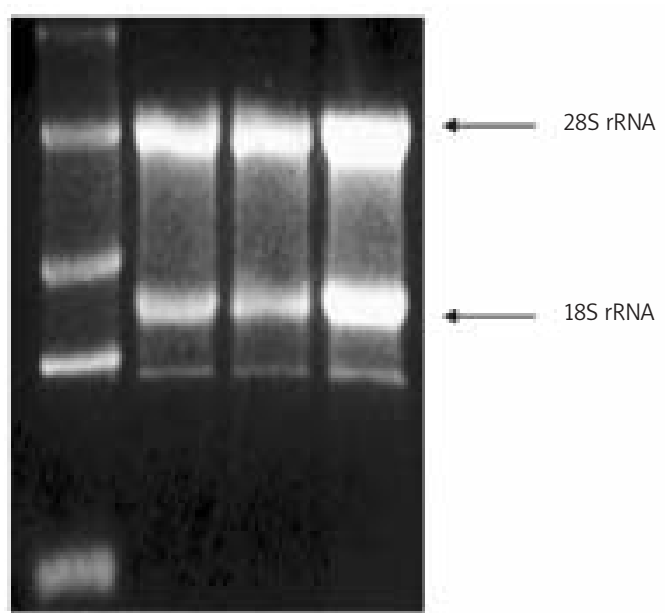

Figure 1.

(sample electrophoresis shown in Fig. 1) in 1\% agarose gel stained with ethidium bromide, and quantified spectrophotometrically (Gene Quant II by Pharmacia).

\section{Primers}

Primers and probes for amplification of TGF $\beta 1$ and its type I (ALK5), and II receptors were determined using the Primer Express Version 1.0 computer program (PE Applied Biosystems, USA), and their sequence homologies were checked using the GenBank database (http://www.ncbi.nlm.nih. gov/irx/genbank).

Primer sequences were ( $f$ - forward; $r$ - reverse): TGFß (f) 5' TGGAACCGGCCTTTCCTGCTTCTCATG 3'

(r) 5' GCGGAAGTCAATGTACAGCTGCCGC 3' TGF $\beta$ receptors TGF $\beta$ RI

(f) 5' ACTGGCAGCTGTCATTGCTGGACCAG 3'

(r) 5' CCTGAGCCAGAACCTGACGTTGTCATATCA 3' TGF $\beta$ RII (f) 5' GGCTCAACCACCAGGGCATCCAGAT 3 (r) 5' CTCCCCGAGAGCCTGTCCAGATGCT 3

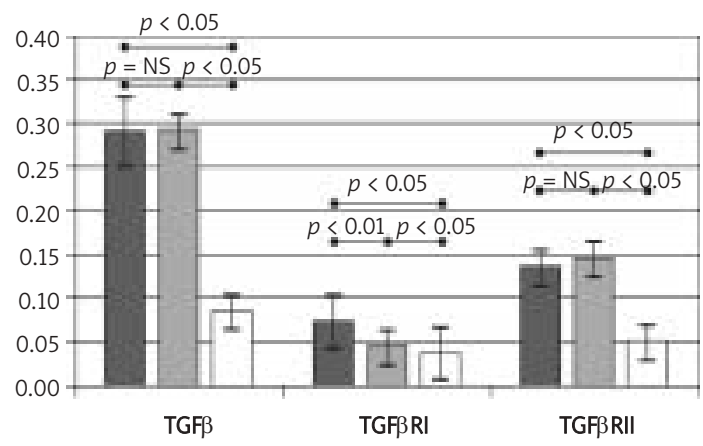

- OZW (1 doba) घ OZW (5 doba) घGrupa kontrolna

Figure 2. Gene expression of TGF $\beta-1$ and its receptors $\mathrm{RI} i \mathrm{RII}$ in peripheral blood monocytes
The $\beta$-actin gene was used as the endogenous control and was amplified simultaneously with assessed genes. Primer sequences used for $\beta$-actin amplification were:

(f) 5' TCACCCACATGTGCCCATCTACGA 3'

(r) 5' CAGCGGAACCGCTCATTGCCAATGG 3'

\section{Real-time PCR (QRT-PCR)}

In order to determine the number of mRNA copies for TGF $\beta$ and its type I and II receptors, quantitative reverse transcriptase polymerase chain reaction (QRT-PCR) was performed using QuantiTect SYBR Green RT-PCR. Cycling conditions were as follows: RT: $60^{\circ} \mathrm{C} 30$ for min; polymerase activation: $94^{\circ} \mathrm{C}$ for $15 \mathrm{~min}$; PCR: $94^{\circ} \mathrm{C}$ for $15 \mathrm{~s}$ and $53-68^{\circ} \mathrm{C}$ for $30 \mathrm{~s}, 40$ cycles; final elongation: $72^{\circ} \mathrm{C}$ for $10 \mathrm{~min}$. QRT-PCR specificity was confirmed experimentally by PAA electrophoresis, amplimers' melting temperature measurement using ABI PRISM7000 (SYBR Green RT-PCR Kit), and sequence analysis using ABI PRISM 377 DNA Sequencer (PE Applied Biosystems). The results are shown as studied gene to $\beta$-actin mRNA level ratio.

\section{Statistical analysis}

All values were expressed as means \pm standard error (AVG \pm SEM). Differences were considered to be significant at $p<0.05$. In order to check the normality of the distribution, the Shapiro-Wilk test was performed. In case of a normal distribution Student's t-test was performed; otherwise the Mann-Whitney U test was used. To compare two related variables the Wilcoxon test was used. Analysis of correlation was performed using the Spearman test.

The study was accepted by the Ethics Committee of the Medical University of Silesia.

The investigation conforms to the principles outlined in the Declaration of Helsinki.

\section{Results}

Basic clinical parameters of ACS patients are shown in Table II. The results of gene expression are shown as studied gene to $\beta$-actin mRNA level ratio.

Compared to healthy subjects, ACS patients showed slightly elevated transcriptional activity of genes encoding TGF $\beta 1$ (0.29 \pm 0.043 vs. $0.08 \pm 0.020$, $p<0.05)$ and its receptors RI and RII (0.071 \pm 0.022 vs. $0.036 \pm 0.023, p<0.05 ; 0.134 \pm 0.020$ vs. $0.048 \pm 0.016$, $p<0.05$, respectively). After 5 days of standard treatment a statistically significant decrease in TGF $\beta$ RI gene expression was observed $(0.071 \pm 0.022$ vs. $0.043 \pm 0.021, p<0.01)$ while other studied genes' mRNA level remained similar during the observation period (Fig. 2). Analysis of ACS subgroups revealed that there are no significant 
differences in expression of studied genes at day 1 (although UA tended to have higher TGF $\beta$ RI expression). After 5 days a statistically significant decrease was observed only for the TGF $\beta$ RI gene in the UA group (Table IV).

Additionally, the RI/RII gene expression ratio was evaluated. On the day of ACS, the RI/RII ratio was higher in the study group than in controls $(0.75$ \pm 0.218 vs. $0.42 \pm 0.202$, $p<0.05$ ), but after 5 -day therapy it decreased significantly $(0.75 \pm 0.218$ vs. $0.29 \pm 0.065, p<0.05)$ and was lower than in controls ( $0.29 \pm 0.065$ vs. $0.42 \pm 0.202$, $p<0.05)$. Again, the decrease was more pronounced in UA than in MI subgroups (Table IV).

mRNA level of TGF $\beta 1$ did not correlate with either of the receptors. The expression of genes encoding receptors were not correlated either. Studied gene expression did not differ among ACS subgroups.

No major atherosclerosis risk factors (obesity, smoking, dyslipidaemia, hypertension, age/sex) affected expression of the studied genes. The exception was the TGF $\beta$ RI gene, whose expression was higher in ACS patients with family history of CAD (0.34 \pm 0.159 vs. $0.11 \pm 0.04$; $p<0.05)$. Moreover, the presence of 4 or more classical risk factors correlated with higher level of TGF $\beta$ RI expression $(0.098 \pm 0.035$ vs. $0.028 \pm 0.008 ; p<0.05)$. hsCRP did not correlate significantly either with TGF $\beta$ $(r=0.4 ; p=\mathrm{NS})$ or with $\mathrm{RI}$ and RII receptors ( $r=0.2 ; p=\mathrm{NS}$ and $r=-0.1 ; p=\mathrm{NS}$ respectively).

The analysis of the association between studied gene expression and such clinical variables as ejection fraction, myocardial necrosis markers (CK, CKMB, Tnl), time to $\mathrm{PCl}$ and early risk score assessed by the GRACE model and GFR did not reveal any statistically significant relations. Angiographic findings (e.g. number of affected vessels and ACS-related artery) were not related to studied genes' mRNA levels either.

\section{Discussion}

The effect of TGF $\beta$ on the vascular system has been proven to be protective. According to Grainger's hypothesis, lack of TGF $\beta$ activity leads to a two-step process: If the activity is transiently diminished, an atherosclerotic lesion is formed, but since TGF $\beta$ still stimulates ECM production, it results in a stable plaque phenotype. If TGF $\beta$ activity is chronically reduced, inflammatory processes may lead to the plaque being converted to an unstable phenotype. The data come mostly from animal models of atherosclerosis. The observations in humans, however, particularly those assessing plasma levels of TGF $\beta$ and their correlation with clinical manifestation of atherosclerosis, remain confusing.

Although Grainger et al. in 1995 published their data proving that patients with atherosclerosis had
Table IV. Gene expression of TGF- and its receptors in ACS subgroups

\begin{tabular}{|c|c|c|c|}
\hline \multirow[b]{2}{*}{$\begin{array}{l}\text { Gene } \\
\text { expression }\end{array}$} & \multicolumn{3}{|c|}{ ACS subgroups } \\
\hline & $\begin{array}{l}\text { STEMI } \\
(n=14)\end{array}$ & $\begin{array}{l}\text { NSTEMI } \\
(n=9)\end{array}$ & $\begin{array}{c}\text { UA } \\
(n=9)\end{array}$ \\
\hline$T G F \beta-1$ (day 1) & $0.29 \pm 0.05$ & $0.23 \pm 0.05$ & $0.34 \pm 0.12$ \\
\hline$T G F \beta-1$ (day 5) & $0.33 \pm 0.06$ & $0.26 \pm 0.05$ & $0.26 \pm 0.04$ \\
\hline$T G F \beta R I$ (day 1) & $0.04 \pm 0.01$ & $0.03 \pm 0.01$ & $0.15 \pm 0.07$ \\
\hline TGF $\beta R I$ (day 5) & $0.07 \pm 0.05$ & $0.03 \pm 0.004$ & $0.02 \pm 0.004^{*}$ \\
\hline TGF $\beta R / /$ (day 1) & $0.18 \pm 0.04$ & $0.10 \pm 0.02$ & $0.10 \pm 0.02$ \\
\hline TGF $\beta R / I$ (day 5) & $0.11 \pm 0.04$ & $0.24 \pm 0.10$ & $0.10 \pm 0.02$ \\
\hline$T G F \beta R I / R / I$ (day 1 ) & $0.35 \pm 0.07$ & $0.56 \pm 0.30$ & $1.47 \pm 0.61$ \\
\hline$T G F \beta$ RI/RII (day 5) & $0.40 \pm 0.16$ & $0.22 \pm 0.06$ & $0.24 \pm 0.05^{*}$ \\
\hline
\end{tabular}

${ }^{*} p<0.05$ statistically significant difference vs. day 1 values

severely depressed circulating levels of TGF $\beta$ [9], some later reports agreed with the findings [10], while some others did not find any correlation of TGF $\beta$ and atherosclerosis [11] or even suggested that atherosclerotic patients have increased TGF $\beta$ levels $[12,13]$. The discrepancies are mostly due to methodology: some investigators assessed total cytokine, while some others assessed active cytokine. It is noteworthy that investigators who observed low levels of active TGF $\beta$ also noted similar or even elevated concentrations of total TGF $\beta$ in the atherosclerotic population compared to healthy controls. The reason for low levels of active cytokine in CAD subjects might be that in this group of patients high levels of TGF $\beta$ inhibitors (e.g. lipoprotein (a), plasminogen activator inhibitor type 1) are observed [14, 15].

Recently the emphasis has been on leukocytes as a potential source of TGF $\beta$. It is not clear, however, which population is the main source. In this study we have observed elevated transcriptional activity of genes encoding TGF $\beta 1$ and its two receptors in circulating monocytes of ACS patients. If blood monocytes are to be considered an important source of circulating cytokines, our finding would confirm the data that in atherosclerosis TGF $\beta$ production is not diminished or can even be increased. On the other hand, recent findings of Kempf et al. [16] as well as our previous report [17] show that TGF $\beta$ mRNA expression in $P B M C$ is lower in CAD subjects. The reason might be that PBMC are a heterogeneous group of cells (e.g. a high proportion of lymphocytes) and our new data seem to provide more detailed information. Our study showed increased gene expression of TGF $\beta$ in all clinical forms of ACS with no differences among ACS subgroups.

Besides TGF $\beta$ itself, changes in TGF $\beta$ receptor signalling play an important role in the evolution of atherosclerotic lesions. In the normal vessel wall, 
expression of TGF $\beta$ type II receptor predominates, while in the pathological condition TGF $\beta$ RI signalling increases. In the present study transcriptional activity of TGF $\beta$ receptor genes was elevated along with the cytokine gene. The RI/RII expression ratio was the highest on the first day of ACS, which means that the balance was more toward the "pathological" RI receptor. 5-day therapy did not affect either TGF $\beta 1$ gene expression or RII expression, but reduced RI, thus restoring the balance between 'pathological' and 'physiological' receptor. This finding is important considering that receptor disturbances in TGF $\beta$ signalling may have a profound effect on atherosclerosis progression [18]. It is noteworthy, however, that the decrease in TGF $\beta$ RI expression and RI/RII ratio was significantly pronounced only in the UA group. It is possible that the overlap of necrosis-related inflammatory reaction in STEMI and NSTEMI subgroups had some effect on TGF $\beta$ R expression on day 5 , but the design of the study does not allow us to address this issue.

The day 1 sample is considered in the study as prior to treatment status. As mentioned, before the collection patients could only receive emergency ACS treatment, so the treatment given prior to sampling is unlikely to have had any effect on gene expression. Five days of treatment did not affect the monocyte expression of the TGF $\beta$ and RII gene. Although there are a number of articles reporting the effect of statins, ACE inhibitors and aspirin on TGF $\beta[19,20]$, multi-drug therapy varying from patient to patient and the short observation time did not allow us to observe any major effect on the studied genes.

TGF $\beta$ seems to be an independent mechanism in atherogenesis and it is not surprising that in the study we have not observed any linkage between gene expression of TGF $\beta$ or its receptors and classical CAD risk factors, such as hsCRP level, smoking, dyslipidaemia, hypertension and obesity. There are some reports, however, to confirm the mechanistic link between cigarette smoking or dyslipidaemia and TGF $\beta[21,22]$. Although no correlation was found between studied genes and particular risk factors, patients with a higher total risk score (e.g. more than 3 risk factors) presented with elevated level of TGF $\beta$ RI gene expression, which is further proof that the balance in the receptors is important in maintaining proper TGF $\beta$ signalling and its protective action. In the subsequent analysis patients with a family history of CAD had a higher gene expression of "pathological" TGF $\beta$ RI receptor and, consequently, increased RI/RII ratio. The gene of TGF $\beta$ itself did not differentiate the groups. There are no data in the literature to prove that molecular disturbances in TGF $\beta$ signalling might be one of the genetic backgrounds of atherosclerosis, and this is a novel finding in this study. A few polymorphisms have been identified to link genetic background and ACS, but they all referred to the TGF $\beta$ gene, not its receptors [23].

Lack of a correlation between studied gene expression and clinical parameters of ACS (including $\mathrm{EF}$, time of chest pain before $\mathrm{PCl}$, necrosis markers) is not surprising given the fact that monocyte gene expression is more likely to reflect a chronic inflammatory process and monocyte activation leading to ACS than the clinical state at the time of the event. Also renal function (eGFR), which is strongly associated with cardiovascular risk (24), due to exclusion criteria was homogeneous in the studied group and did not correlate with monocyte gene expression.

One limitation of the study is the number of patients recruited. An increased number would possibly reveal some relationships that did not meet statistical significance here. The exclusion criteria, however, were set to keep study subgroups relatively homogeneous. Another issue is that the study protocol does not allow us to distinguish whether studied gene expression changes were due to the chronic atherosclerotic process or acute plaque rupture. Although a stable CAD group would provide some more information on this matter, it is difficult to obtain a relatively homogeneous stable angina group with similar treatment, which, presumably, is an important factor affecting gene expression.

The altered gene expression observed here in monocytes of ACS patients reflects a systemic reaction to atherosclerosis, and the part TGF $\beta$ takes in it. It would be of interest to evaluate it in lymphocytes as well, and to correlate these findings with circulating levels of TGF $\beta$.

In conclusion, monocytes of ACS patients demonstrate overexpression of TGF $\beta 1$ and its receptors' genes, which suggests activation of protective mechanisms in ACS. Increased TGF $\beta$ RI expression in high risk patients may reflect the significance of this receptor in pathology of atherosclerosis. 5-day standard treatment downregulated the TGF $\beta$ RI gene but did not affect TGF $\beta 1$ and TGF $\beta$ RII.

\section{References}

1. Libby $P$, Ridker PM, Maseri A. Inflammation and atherosclerosis. Circulation 2002; 105: 1135-1143.

2. Javelaud D, Mauviel A. Mammalian transforming growth factor-betas: Smad signaling and physio-pathological roles. Int J Biochem Cell Biol 2004; 36: 1161-1165.

3. Miyazono K. Transforming growth factor-beta and its receptors. Nippon Yakurigaku Zasshi 1996; 107: 133-140.

4. Grainger DJ. Transforming growth factor beta and atherosclerosis: so far, so good for the protective cytokine hypothesis. Arterioscler Thromb Vasc Biol 2004; 24: 399-404. 
5. Argmann CA, Van Den Diepstraten CH, Sawyez CG, Edwards $J Y$, Hegele RA, Wolfe BM, Huff MW. Transforming growth factor-betal inhibits macrophage cholesteryl ester accumulation induced by native and oxidized VLDL remnants. Arterioscler Thromb Vasc Biol 2001; 21: 2011-2018.

6. Gojova A, Brun V, Esposito B, Cottrez F, Gourdy P, Ardouin $P$, Tedgui A, Mallat Z, Groux H. Specific abrogation of transforming growth factor-beta signaling in T cells alters atherosclerotic lesion size and composition in mice. Blood 2003; 102: 4052-4058.

7. Mallat Z, Gojova A, Marchiol-Fournigault C, Esposito B, Kamaté C, Merval R, Fradelizi D, Tedgui A. Inhibition of transforming growth factor-beta signaling accelerates atherosclerosis and induces an unstable plaque phenotype in mice. Circ Res 2001; 89: 930-934.

8. Lutgens E, Gijbels M, Smook M, Heeringa P, Gotwals P, Koteliansky VE, Daemen MJ. Transforming growth factorbeta mediates balance between inflammation and fibrosis during plaque progression. Arterioscler Thromb Vasc Biol 2002; 22: 975-982.

9. Grainger DJ, Kemp PR, Metcalfe JC, Liu AC, Lawn RM, Williams NR, Grace AA, Schofield PM, Chauhan A. The serum concentration of active transforming growth factorbeta is severely depressed in advanced atherosclerosis. Nat Med 1995; 1: 74-79.

10. Stefoni S, Cianciolo G, Donati G, Dormi A, Silvestri MG, Colí L, De Pascalis A, lannelli S. Low TGF-beta1 serum levels are a risk factor for atherosclerosis disease in ESRD patients. Kidney Int 2002; 61: 324-335.

11. Djurovic S, Thelle DS, Ringstad J, Christensen B, Berg K. Altered serum concentrations of TGF-beta 1 and Lp(a) lipoprotein and their correlation in patients with first acute myocardial infarction. Nutr Metab Cardiovasc Dis 1999 ;9: 250-254.

12. Slevin M, Krupinski J, Slowik A, Kumar P, Szczudlik A, Gaffney J. Serial measurement of vascular endothelial growth factor and transforming growth factor-betal in serum of patients with acute ischemic stroke. Stroke 2000; 31: 1863-1870.

13. Wang XL, Liu SX, Wilcken DE. Circulating transforming growth factor beta 1 and coronary artery disease. Cardiovasc Res 1997; 34: 404-410.

14. Grainger DJ, Kemp PR, Liu AC, Lawn RM, Metcalfe JC. Activation of transforming growth factor-beta is inhibited in transgenic apolipoprotein(a) mice. Nature 1994; 370: 460-462.

15. Byrne CD, Wareham NJ, Martensz ND, Humphries SE, Metcalfe JC, Grainger DJ. Increased PAI activity and PAI-1 antigen occurring with an oral fat load: associations with PAI-1 genotype and plasma active TGF-beta levels. Atherosclerosis 1998; 140: 45-53.

16. Kempf K, Haltern G, Füth R, Herder C, Müller-Scholze S, Gülker H, Martin S. Increased TNF-alpha and decreased TGF-beta expression in peripheral blood leukocytes after acute myocardial infarction. Horm Metab Res 2006; 38: 346-351.

17. Dabek J, Mazurek U, Gasior Z, Wilczok T, Kulach A, KuciaKuzma S. Transcriptional activity of genes encoding Transforming Growth Factor beta and its receptors in peripheral blood mononuclear cells from patients with acute coronary syndromes. Int I Cardiol 2006; 111: 275-279.

18. Robertson AK, Rudling M, Zhou X, Gorelik L, Flavell RA, Hansson GK. Disruption of TGF-beta signaling in T cells accelerates atherosclerosis. J Clin Invest 2003; 112: 13421350.

19. Wibaut-Berlaimont V, Randi AM, Mandryko V, Lunnon MW, Haskard DO, Naoumova RP. Atorvastatin affects leukocyte gene expression in dyslipidemia patients: in vivo regulation of hemostasis, inflammation and apoptosis. J Thromb Haemost 2005; 3: 677-685.

20. Peters H, Rückert M, Gaedeke J, Liefeldt L, Ketteler M, Sharma AM, Neumayer HH. Angiotensin-converting enzyme inhibition but not beta-adrenergic blockade limits transforming growth factor-beta overexpression in acute normotensive anti-thy1 glomerulonephritis. J Hypertens 2003; 21: 771-780.

22. Cucina A, Sapienza P, Corvino V, Borrelli V, Mariani V, Randone B, Santoro D'Angelo L, Cavallaro A.Nicotine induced smooth muscle cells proliferation is mediated through bFGF and TGF-beta1. Surgery 2000; 127: 316-322. 22. Leonarduzzi G, Sevanian A, Sottero B, Arkan MC, Biasi F, Chiarpotto E, Basaga H, Poli G. Up-regulation of the fibrogenic cytokine TGF-beta1 by oxysterols: a mechanistic link between cholesterol and atherosclerosis. FASEB J 2001; 15: 1619-1621.

23. Cambien F, Ricard S, Troesch A, Mallet C, Generenaz L, Evans A, Arveiler D, LuC G, Ruidavets JB, Poirier O. Polymorphisms of the transforming growth factor-beta 1 gene in relation to myocardial infarction and blood pressure. The Etude Cas-Temoin de l'Infarctus du Myocarde (ECTIM) Study. Hypertension 1996; 28: 881-887. 24. Barylski M, Banach M, Mikhailidis DP, Pawlicki L, Kowalski J. Decreased kidney function as a risk factor for cardiovascular events in subjects with metabolic syndrome - a pilot study. Arch Med Sci 2008; 4: 417-423. 